\title{
Influence of Ascorbic Acid Application on Quality and Storage Life of Fruits
}

\author{
Jatinder Singh and Anis Mirza* \\ Department of Horticulture, Lovely Professional University, Phagwara-144411, India \\ * Corresponding author
}

\section{A B S T R A C T}

\begin{tabular}{|l|}
\hline K e y w or d s \\
$\begin{array}{l}\text { Physical, Biochemical } \\
\text { Changes, Ascorbic } \\
\text { acid, Spoilage, } \\
\text { Physiological loss in } \\
\text { weight }\end{array}$ \\
\hline Article Info \\
\hline $\begin{array}{l}\text { Accepted: } \\
\text { 30 June } 2018 \\
\text { Available Online: } \\
\text { 10 July } 2018\end{array}$ \\
\hline
\end{tabular}

\begin{abstract}
India is major producer of fruits of the world with $2^{\text {nd }}$ ranking. An appreciable quantity of produce is lost due to multitude of factors such as improper post-harvest operations, perishable nature; as a result, there is a huge gap between production and availability. About $10-15 \%$ fresh fruits shrivel or spoil, lowering market value along with consumer acceptability. Quality cannot be improved during storage. Selection of fruit varieties is based on marketability, yield and keeping quality because these factors affect the bottom line. Use of protective antioxidants for enhancement in shelf life of produce has been in practice and yielded appreciable results. Contributing to the list of protectants, ascorbic acid finds suitability as a preferential post harvest dip agent for shelf-life enhancement and keeping the fruit properties intact for longer durations. This article provides a comprehensive essay of the protective action of ascorbic acid treatments in fruits for enhancing the shelf-life.
\end{abstract}

\section{Introduction}

Fruit are important sources of fiber, potassium, folic acid, carbohydrates and vitamins etc. They constitute vital part of our diet. Their minor documented benefits relate to their role in preclusion of cancer and kidney functions through contribution of ascorbic acid. Vitamin C is needed for growth, development and repair of cells and tissues. It helps in making collagen in the body, leading various proteins in skin making, cartilage, ligaments, tendons and blood vessels and healing wounds. Vitamin $\mathrm{C}$ is an excellent antioxidant, along with beta-carotene, and many other nutrients. Researchers found that pre-harvest prevailing conditions such as climate, light, soil type, mulching, fertilization and application of naturally occurring compounds can affect the nature of the antioxidant and antioxidant activity of various fruits (Antalovich et al, 2002). Various researchers have reported Ascorbic acid as effective measure in controlling enzymatic browning of fruits and vegetables (Santerre $e t$ al., 1988; Sapers et al., 1989). Various kinds of molds (Fungi) in different nuts that are already roasted can be removed by application of with and ascorbic acid solution along with water (Clark, 2015). Ascorbic acid is a good antioxidant that keeps fruit from darkening and improves destruction of bacteria during 
drying process. A combination of 34 grams of pure ascorbic acid into 1000 milliliters of cold water averts darkening of fruits. Application of Ascorbic acid had many stimulating effects on growth and physiological activities of various plants (Dewick, 2000, Ismail, 2008 and Abdou et al., 2015). Antioxidants like ascorbic acid and citric acid have synergistic effect and auxinic action towards flowering and fruiting of fruit trees, lately, antioxidants are used instead of auxins for improving growth, development and fruiting of fruit trees (El Sayed et al., 2000 and Maksoud et al., 2009). Ascorbic and citric acid had ability to improve physical and chemical traits of Ruby seedless grapevine (Abdel-Salam, 2016). Antioxidants (like Ascorbic acid etc.) have auxinic and synergistic type influence on flowering and fruiting of various fruit trees. Recently some antioxidants are used instead of auxins and other substances for enhancing growth, development and fruiting of various fruit trees (El Sayed et al., 2000 and Ragab, 2016). Application of Ascorbic acid results in reduction of browning in fruits and vegetables, nitrosamine formation in cured and raw meat products along with reduction of oxidation of fats and lipids and also as a dough conditioner (Takeda, 2014).

\section{Physical changes}

\section{Fruit colour}

Affirmative results regarding colour of winter crop of guava cv. Shweta fruits under ambient conditions after application of Ascorbic acid were achieved during research study. It was recorded that fruit colour changed gradually as the storage period progressed. Colour of the fruits was of green colour when harvested. Various concentration of Ascorbic acid successfully maintained the fruit colour and exhibited ultimately light yellow green colour at the end of storage (Kaur, 2016). It was discovered at Indira Gandhi Krishi
Vishwavidyalaya, Raipur that application of sulphur +citric acid in China fruits, showed minor browning with the uppermost score of fruit colour. Five varieties of litchi (viz. Sarguja Selection-1, Sarguja Selection-2, Shahi, China and Rose Scented) were treated with various chemicals during experiment and kept under ambient storage conditions (Jain, 2006). Ascorbic acid $0.1 \%$ increased the lightness (L) and decreased the redness (a) and yellowness (b) color values in peach, strawberry and apple fruit (Rababah et al., 2005). The sensory features of the papaya fruits exhibited the overall advancement with application 1.5 per cent of chitosan concentration, after 5 weeks of cold storage (Ali et al., 2011). It was found that Ascorbic acid has been very effective in discoloration deterioration and helpful in reduction of browning in mushroom (Hsu et al., 1988). Many of researchers used $0.75 \%$ ascorbic acid to reduce browning of apple (Ponting et al., 1994). Mc Evily et al., (1992) discovered that Ascorbic acid is commonly used to prevent enzyme discoloration of fruits by reduction of colorless o-quinones to diphenols compound.

\section{Fruit firmness}

Treated guava fruits of cv. Allahabad Safeda with Ascorbic acid 100 ppm, stored under cold room conditions showed lowest firmness loss after 21 days of storage (Gill et al., 2014). It was recorded in winter guava cv. Shweta that Ascorbic acid had influenced the fruit firmness under ambient storage conditions as compare to control (Kaur, 2016). Maximum mean fruit firmness was discovered in ber fruits treated with Ascorbic acid (Kaur, 2011). Spray of antioxidants gave exceptional result on growth and bunch characteristics of grapes cv. Thompson Seedless (Fayed, 2010). Softening of fruits might be caused either by breakdown of insoluble protopectin into soluble pectin or by hydrolysis of the starch as in banana fruit (Mattoo et al., 1975). 
Application of Ascorbic acids caused increase in firmness and fruit weight in mango fruit (Awad, 2006). It was reported that $1.5 \%$ CTS, alone or in combination with $10 \mathrm{mmol} \mathrm{L-1}$ ascorbic acid retained greater firmness and postponed the increase of weight loss than controls in 'Yali' pears (Lin et al.,2008). Ascorbic acid proved to be effective in increasing peach fruit firmness (El-Shazly, 2013). Tomar and Kumar (1977) revealed that application ascorbic acid has resulted in increased acidity in grape var. 'Perlette' and also enhanced the bunch shape.

\section{Palatability rating}

It was proved under ambient conditions that guava fruit treated with Ascorbic acid @ 2.0 percent continued palatable up to 7 th day and afterwards it declined considerably (Kaur, 2016). Treatment with ascorbic acid enhanced consumer acceptability in mango (Ahmad, 1998). Development of acids and sugars of palatability rating in guava fruits during storage might be due to the development as a consequence of hydrolysis of starch and other molecules leading to the development of flavour in fruits (Bal, 1982). The raise in organoleptic rating score under storage condition may be due to slow tempo of biochemical processes resulting from decreased transpiration and respiration rate. It was revealed in winter guava cv. 'Allahabad Safeda' that Ascorbic acid @100 ppm application retained satisfactory organoleptic rating up to 21 days in cold storage (Gill et al., 2014).

\section{Physiological loss in weight}

Ascorbic acid $100 \mathrm{ppm}$ treated guava fruits cv. Allahabad Safeda exhibited minimum weight loss. Treated fruits of winter guava cv. Shewta with Ascorbic acid @ 1.0 per cent showed less PLW than untreated (Kaur, 2016). Ascorbic acid $1000 \mathrm{ppm}$ in grapes caused lower cumulative physiological loss in weight (Ling et al., 2007). Similar results are reported by in pear (Ling et al., 2007) and ber (Siddiqui et al., 1995). Maximum fruit spoilage was accessed in control followed by Ascorbic acid treatment. Foliar application of ascorbic acid has positive effect on weight and dimensions of the berry (ber) fruit (Kaur, 2016). These results are supported by various researchers (Maximos et al., 1995 and Wassel, 1985). Ascorbic acid might reduce the production of ethylene and respiration processes by hindering the probable free radical intervening ACC to pathway of ethylene (Apelbaum et al., 1981a). Experimentation with "Anna" apple revealed that physical and chemical characteristics were enhanced by spraying citric acid at $0.1 \%$ at start of growth, just after fruit set and at 21 days later (Ahmed and Abd, 2007). It was proved in "Swelling" peach trees that foliar application of ascorbic acid lead to an increase in fruit weight (Gill et al., 2014). Weight loss of 5 per cent under storage conditions, is the highest permissible limit in case of fruits, above which the fruits exhibit shriveling and becomes unmarketable (Mahajan et al., 2009). PLW increased during the storage period regardless of Ascorbic acid treatment. While working in winter guava cv. 'Allahabad Safeda it was reported that Ascorbic acid treated fruits registered the minimum mean PLW. It was observed that the average PLW decreased appreciably by boosting the concentration of Ascorbic acid (Gill et al., 2014). It was established in ber fruits that treatment with Ascorbic acid @ 100 ppm at low temperature storage declined the physiological loss (Banik et al.,1988). Application of Ascorbic acid @ 2 per cent caused least physiological weight loss in ber fruits (Kaur, 2014). Minimum physiological weight loss was noted after 7 days and maximum after 28 days of storage. The PLW was drastically increased with prolongation of storage. Ascorbic acid seems to be an effective antioxidant for improving yield, fruit weight 
content of olive trees (Maksoud et al., 2009). Sun et al., (2010) recorded higher TSS, acidity and lower weight loss and decay rate in litchi fruits treated after harvest with Ascorbic acid. Ozdemir and Gökmen (2017) proved that chitosan-ascorbic acid coating has no effect on physiological weight loss whereas the control treatment, $1 \%$ ascorbic acid and coated fruits lost alike weight during storage of 28 days. Puthmee et al., (2010) recorded that applications of ascorbic acid were very effective in reducing fruit weight loss, microbial growth and color changes.

\section{Fruit spoilage}

It was revealed that Ascorbic acid treatments significantly decreased the post-harvest losses and extended shelf-life of the guava fruits (Jayachandran et al., 2007). Ascorbic acid protected various fruits against harmful effects of oxidative processes and biotic stresses due to improved levels of antioxidants that might prevent much softening and rotting of fruits (Paliyath et al., 2008). Application of Ascorbic acid @100 ppm showed least decay incidence score in guava. However, low concentration of Ascorbic acid was found at par; yet significantly in minimize decay incidence (Gill et al.,2014). Least spoilage was reported in ber fruits when Ascorbic acid was applied (Banik et al.,1988 and Siddiqui and Gupta,1989). Fruit spoilage was less in ber fruit in Ascorbic acid 2 per cent treatment when kept in cold storage (Kaur, 2014).

\section{Bio-chemical changes}

\section{Total soluble solids}

Application of Ascorbic acid 100 ppm in winter guava cv. 'Allahabad Safeda' exhibited higher TSS (Gill et al., 2014). Treatment with Ascorbic acid @ 150 and 300 ppm enhanced TSS (Siddiqui, S. and Gupta, 1989). It was reported in mango fruits cv. Alphonso and
"Badami" that spraying with Ascorbic and citric acids at 200, 300 and 400 ppm, improved many bio chemical characters like total soluble solids, ascorbic acid and total sugars (Awad, 2006). Spraying with ascorbic acid along with $\mathrm{GA}_{3}$ improved "Canino" apricot quality. $\mathrm{GA}_{3}$ at 25 and $50 \mathrm{ppm}$ along with ascorbic acid at $50 \mathrm{ppm}$ had no significant influence towards TSS (\%) of plum fruits (Nabil et al., 2013). TSS of guava fruits was at its lowest with Ascorbic acid 1000 ppm stored under ambient conditions (Rajput et al., 2015). When ber fruits were applied with Ascorbic acid, exhibited an enhancement in TSS but followed a decreasing trend at later period of storage (Kaur, 2011). Strawberry (Camarosa and Red Dream varieties) and Raspberry (Killarney and Nova varieties) fruits were harvested in Georgia and treated with $0 \%, 1 \%$ or $2 \%$ solution of Ascorbic acid at $20 \pm 1{ }^{\circ} \mathrm{C}$ temperature and stored at $-40{ }^{\circ} \mathrm{C}$. It was accomplished that after 3 months of storage period that TSS of raspberry and strawberry fruits were declined by $10-14 \%$ in treated and controlled samples (Turmanidze et al., 2017).

\section{Acidity}

Under normal conditions that Ascorbic acid @ 2.0 per cent exhibited advanced level of acidity in winter crop of guava cv. Shweta. Minimum acid content was observed in untreated fruits. A decline in acidity and amplification in $\mathrm{pH}$ of fruit was recorded during the storage period in lemon (Pesis et al., 1999). Liu et al., (2006) submitted that isoascorbic acid had a good effect in sustaining quality of litchi fruit quality in terms of TSS, titratable acidity and ascorbic acid of the pulp.

Reduction in acid content of guava fruits with the enhancement in storage duration might be endorsed to the use of organic acids in respiration process by the cells and change of 
acids into total sugars (Echeverria and Valich, 1989). Guava fruits treated with Ascorbic acid retained advanced acidity during the storage, probably due to postponed ripening process. Similar values also have been established in guava by different research workers (Jayachandran et al., 2005). Acid content in guava followed a declining fashion during cold storage. Decline in the acid content of the fruit was more rapid in the untreated guava fruits whereas treated fruits were recorded a regular descending acidity level (Gill et al., 2014). Post-harvest dipping in Ascorbic acid solution@150 and 300 ppm had no effect towards acidity (Siddiqui and Gupta, 1989). It was revealed in ber that the acid content of fruits stored under room temperature $\left(25 \pm 5^{\circ} \mathrm{C}\right)$ was not affected by Ascorbic acid (300 ppm) treatment (Siddiqui and Gupta,1995). When fruits of Ziziphus jujuba cv. Linyilizao were dipped in different concentrations of citric acid (0.5, 1.0 and $1.5 \%$ ) for 3 hours and stored under refrigerator $\left(4^{\circ} \mathrm{C}\right)$ conditions revealed that citric acid treatment @ 0.5 percent was more effectual towards titratable acidity (Hossain et al.,2014). Kumar et al., (2009) reported higher TSS, titratable acidity and ascorbic acid in fruits of litchi treated with $1.0 \%$ iso ascorbic acid after 6 days of harvest process.

\section{Vitamin C}

A declining trend was recorded after treatment with Ascorbic acid $(0.2 \%$ and $0.3 \%)$ low temperature $\left(4^{\circ} \mathrm{C}\right)$ in guava (Hossain et al., 2014). Decrease in Ascorbic acid during storage could be due to alteration of Ascorbic acid to dehydroAscorbic acid or due to action of Ascorbic acid oxidase (Mapson, 1970). When fruits of winter guava cv. 'Allahabad Safeda' treated with Ascorbic acid 100 ppm revealed maximum Vitamin C content (Gill et al., 2014). Maximum vitamin $\mathrm{C}$ content was observed in guava fruits with treatment of Ascorbic acid @2.0 percent under cold storage (Kaur, 2016). It was observed that post-harvest treatment in Ascorbic acid@150 and 300 ppm had no effect on Ascorbic acid in storage (Siddiqui and Gupta, 1989). It was accessed that when ber fruits were treated with Ascorbic acid, exhibited an enhancement in total sugars up to 14 days of storage but trailed a decrease in later phase of storage. Higher retention of vitamin $\mathrm{C}$ was observed in fruits of ber with Ascorbic acid application (Kaur, 2011).

It was revealed that maximum vitamin $\mathrm{C}$ content in guava cv. Shweta fruits caused with application of Ascorbic acid @ 2.0 per cent under ambient conditions (Kaur, 2016). Citric acid applications had no adverse effect on Ascorbic acid of ber in cv. Gola, with progression of the storage period (Banik et al.,1988). It was proved that treatment with Ascorbic acid @300 ppm in ber cv. Umran, had no effect towards Vitamin C (Siddiqui and Gupta, 1995). Various citric acid treatments resulted in the highest level of the Ascorbic acid in Zizyphus jujuba fruits. Excellent results by application of citric acid @ 1.5\% (Zhao et al., 2009). Treatment of ascorbic acid resulted in improved yield and fruit quality of the olive trees (Makaoud et al., 2009). Kumar et al., (2013) reported higher TSS, titratable acidity and ascorbic acid in litchi fruits treated with iso ascorbic acid after harvest. Spanou and Giannouli, (2013) discovered that the combination of carboxyl methyl cellulose and sodium alginate with ascorbic acid or with green tea can be used as a potential moisture barrier, causing resulting increase potato samples self-life. They suggested that both green tea and ascorbic acid are potential inhibitors of dehydration and natural antioxidants.

\section{Total sugars}

Total sugars were increased during storage in ber. This increase was might be due to the 
dehydration, as the fruits in most of the applications including Ascorbic acid @ 1 per cent (Jawanda et al.,1980b). Minimum total sugar was recorded in ber when treated with Ascorbic acid @100 ppm. Highest total sugars were observed in ber fruits when treated with Ascorbic acid 3 per cent (Banik et al.,1988). Maximum total sugars were noted in fruits with Ascorbic acid 2 per cent followed by Ascorbic acid 3 per cent after $7^{\text {th }}$ days of storage. After 14 days of ambient storage, highest total sugars were observed in Zizyphus jujube (Zhao et al., 2009). Spraying of ascorbic acid in "Kelsey" plum trees, improved fruit quality as compared with the controlled trees (Mohamed, 2008). Spraying of ascorbic acid on "Le- Conte" pear fruits that improved total and non-reducing sugars (Hafez et al., 2010). When ber fruits were dipped in Ascorbic acid, displayed an increase in total sugars up to 14 days of storage but followed a decline trend at later period of storage (Kaur,2011). It was explained in olive trees that application of ascorbic acid 2000 ppm enhanced yield and fruit quality. Where, reduction in concentration up to $1000 \mathrm{ppm}$ had worthless effect (Maksoud et al., 2009). An increase in sugar content of tomato crop was reported by foliar application of ascorbic acid (Biacs et al.,1988). Increase in TSS as a result of ascorbic acids sprays may be due to its influence in increasing photosynthetic pigment which revealed on photosynthesis process and led to enhance in carbohydrate content (Fayed, 2010). Nehra et al., (1987) recorded significant increase in seed yield per plant and the effect was found to be reliant on the used quantities of ascorbic acid.

In conclusion, different concentration of Ascorbic acid was helpful in retaining fruit colour and exhibited ultimately light yellow green colour at the end of storage. Its application maintained significantly higher firmness, enhancement in consumer acceptability and reduction of post-harvest losses along with lowering of cumulative physiological loss in weight along with satisfactory organoleptic rating. But it has no significant effect on spoilage of fruits. Ascorbic acid @2.0 per cent exhibited advanced level of acidity and revealed maximum vitamin $\mathrm{C}$ content. Highest total sugars were recorded in its treatment. Ascorbic acid@100 ppm displayed higher TSS under cold storage.

\section{References}

Abdel-Salam, M. 2016. Effect of Foliar Application with Humic Acid and Two Antioxidants on Ruby Seedless Grapevine. Middle East J. Agric. Res., 5(2): 123-131

Abdou, M.A.H., E.E.T. Ahmed and Ibrahim, T.I.E. 2015. Effect of nitrogen sources and ascorbic acid on growth and essential oil production of geranium pelargonium graveolens, 1.) Plants. Scientific J. Flowers \& Ornamental Plants, 2(2):157-165

Ahmad, M.N. 1998. Studies on the Effect of Post-Harvest Application of Polyamines and Antioxidants on Shelf-Life of Mango cv. Baneshan; M.Sc. Thesis, Acharya NG Ranga Agricultural University, Hyderabad

Ahmed, F.F. and Abd El-All, A.M.K. 2007. Influence of spraying seaweed extract and citric acid on yield and fruit quality of "Anna" apple trees. 1st Inter. Conf. Desert Cultivation Problems and Solutions, Minia Univ. 27-29; pp. 253-261

Ali, A., M. T. M Muhammad, K., Sijam and Siddiqui, Y. 2011. Effect of chitosan coatings on the physicochemical characteristics of Eksotika II papaya (Carica papaya L.) fruit during cold storage. Food chemistry; 124 (2), 620626

Antalovich, M., P.D. Prenzler, E. Patsalides, 
S. McDonald and Robards K. 2002. Methods for testing antioxidant activity. Analyst, 127, 183-198

Apelbaum, A., Y. Shiow, A. Wang, Burgon, J. E. Baker and Lieberman, M. 1981a. Inhibition of the conversion of 1 Amino cyclopropane-1-corboxylic acid to ethylene by structural analog inhibitors of electron transfer. Uncouplers of oxidative phosphorylation and free radial scavengers. Plant Physiology. 67: 7479

Awad, R.U.A. 2006. Effect of some natural pre-harvest treatments on mineral content, yield, fruit quality and storability of mango fruits; Ph.D. Thesis, Fac. Agric., Alex. Univ. p. 111

Bal, J. S. 1982. Study on biochemical changes during room and refrigerated storage of ber Prog Hort.; 14: 158-61

Banik D., J. K. Hore, and Sen, S. K. 1988. Studies on storage life of ber (Zizyphus mauritiana Lamk). Haryana J hort Sci.; 17 (1-2): 49-55

Biacs, T.A., H.G. Daood, B. Czinkotai, F. Hajdu and Kiss-Kutz, N. 1988. Effect of tiotavit treatment on the dynamics of tomato fruit ripeness. Acta Horticulturae, 220;433-438

Dewick, P.M. 2000. Medicinal Natural Products: A Biosynthetic Approach 2nd Ed., John Wiley and Sons, N, Y. pp: $306-356$

Echeverria, E., and Valich, J. 1989. Enzymes of sugar and acid metabolism in stored 'Valencia 'oranges. Journal of the American Society for Horticultural Science (USA)

El Sayed, M.A., A.A. Mervat, and Ali, A.H. 2000. Response of flame seed less grapevine to application of ascorbic acid. The 2nd Conf. Agric. Sci. Assiut, Egypt, pp: 317-340

El-Shazly, S. M., A. M. Elisa, A. M. H. Moảtamed and Kotb, H.R.M. 2013.
Effect of Some Agro-Chemicals and Preharvest Foliar Application on Yield and Fruit Quality of" Swelling" Peach Trees. Alex. J. Agric. Res. Vol. 58, No.3, pp.219-229

Fayed, T.A. 2010. Effect of some antioxidant applications on growth, yield and bunch characteristics of "Thompson Seedless" grapevine. American Eurasian, Agric\& Environ. Sci. 8(3): 322-328

Gill, K.B.S., H.S. Dhaliwal and Mahajan, B.V.C. 2014.Effect of post-harvest treatment of Ascorbic acid on shelf life and quality of guava (psidium guajava L.) Cv. Allahabad Safeda. Int. J. Agric.Sc \& Vet.Med.; Vol. 2, No. 1

H. Clark. 2015. Moldy Foods and Aflatoxin, World Press and Athualpa, ch. 3, pp. 381-395

Hafez, O. M., H. A. Hamouda and Abd- ElMageed, M.A. 2010. Effect of calcium and some antioxidants treatments on storability of "Le- Conte" pear fruits and its volatile components. Nature and Science. 8(5): 109-126

Hossain, Md., Fuad, Parvez Khasru., Anowar, Md., Munshi, M. K., Khalil Md. 2014. Ibrahim and Huque, Roksana. Effect of radiation and chemical treatments on guava (Psidium guajava L.) to delay ripening in relation to organoleptic biochemical and microbiological properties. Int. J. Curr. Microbiol. App. Sci.; 3 (12) 1936

Hsu, A.F., J.J. Shieh, D.D. Bills and White, K. 1988. Inhibition of mushroom polyphenol oxidase by ascorbic acid derivatives, Journal of Food Science 53(3):765-767, 771

Ismail, S.I.I. 2008. Anatomical and Physiological Studies on Nigella sativa, L. Plant. Ph.D. Thesis., Fac. Agric., Mansoura Univ., Egypt, pp: 205-211 
Jain, D.K. 2006. Post-harvest management and storage behaviour of Litchi (Litchi chinensis Sonn); Doctoral dissertation, Indira Gandhi Krishi Vishwavidyalaya, Raipur

Jawanda, J. S., J. S. Bal, J.S. Josan, and Mann, S. S. 1980b. Studies on storage of ber fruit II. Cool temperature.; Punjab Hort. J., 20 (3/4): 56-61

Jayachandran, K. S., D. Srihari, and Reddy, Y. N. 2007. "Post-Harvest Application of Selected Antioxidants to Improve the Shelf Life of Guava Fruit", Acta Hort.; Vol. 735, pp. 627-632

Jayachandran, K.S., D. Srihari, and Reddy, Y.N. 2005. Changes in post-harvest quantity of guava fruits affected by pre-harvest application of growth regulators. Agric. Sci. Digest: 25(3): 210-212

Kaur, Parambir. 2016. Shelf life enhancement studies in Guava (psidium guajava 1 .) Cv. Shweta.; M.Sc. Thesis submitted, PAU Ludhiana

Kaur, Salveen. 2011. Effect of chemicals on storage life and quality of ber cv. Umran.; Doctoral dissertation, PAU Ludhiana

Kumar, M., R. Kumar, and Singh, R. R. 2009. Effect of micronutrients and plant growth regulators on fruiting of litchi. International Journal of Agricultura sciences, 5(2): 521-524

Kumar, R., M.K. Singh and Sodhi, M. 2013.Effect of pre-harvest foliar application of potassium sulphate on storability of ber (Zizyphus mauritiana Lam.). International Journal of Agricultural Sciences, 9(1): 135-138

Lin, L., B. Wang, M.Wang, J. Cao, J. Zhang, , Y. Wu and Jiang, W. 2008. Effects of a chitosan-based coating with ascorbic acid on post-harvest quality and core browning of 'Yali' pears (Pyrus bertschneideri Rehd.). J. Sci. Food Agric.; 88: 877-884
Ling, L., Q. P. Li, B. G. Wang, J. K. Cao and Jiang, W. B. 2007. "Inhibition of Core Browning in 'Yali' Pear Fruit by PostHarvest Treatment with Ascorbic Acid", Journal of Horticultural Science and Biotechnology; Vol. 82, No. 3, pp. 397-402

Liu, H., J. Shi, L. Song, Y. Jiang and You, Y. 2006. Browning control and quality maintenance of litchi fruit treated with combination of $\mathrm{N}$-acetyl cysteine and isoascorbic acid. Journal of Food Technology, 4(2): 147-151

Mahajan, B. V. C., S.R. Sharma and Dhall, R. K. 2009. "Optimization of Storage Temperature for Maintaining the Quality of Guava" J. Food Sci. Technol.; Vol. 46, pp. 604-605

Maksoud, M. A., M. A. Salah, M. S. ElShamma and Faud, A. A. 2009. The effect of biofertilizers and antioxidants on olive trees under calcareous soil conditions. World J Agric Sci.; 5: 35052

Mapson, L.W. 1970. Vitamins in fruits stability of (In) Biochemistry of fruits and their products vol., 1-chapter XII Hulme, AC (Ed.) Academic press, London. pp. 376-377

Mattoo A. K., T. Murata, E. B. Pantastico, K. Chachiss, K. Ogata, C. T. Phan and Pantastico, E. B. (Ed.). 1975. "PostHarvest Physiology, Handling and Utilization of Tropical and Subtropical Fruits and Vegetables"; pp.103-127, The AVI Pub. Co. Inc. Westport Connecticut

Maximos, S.S.E., S. M. El-Nabawi, Nis. Antown and Ghobrial, G.F. 1975. Effect of $\mathrm{GA}_{3}$ sprays and girdling on fruiting and vigor of Thompson seedless grapevines. Annals of Agric. Sci. Moshtohor, Cairo.4, 167-173

McEvily, A.J., R. Inengar, and Otwell, W.S. 1992. Inhibition of enzymatic browning of foods and beverages. 
Critical Reviews in Food Science and Nutrition 32:253-273

Mohamed, H.M.A. 2008. Response of "Kelsey" plum trees to application of some antioxidants. M. Sci. Fac. Agric., Minia University

Nabil, W.A., N. Magda and A. S. Wally. 2013. Effect of Gibberellic Acid Alone or Combined with Two Antioxidants on Fruit Set, Yield and Fruit Quality of "Hollywood" and "Golden Japanese" Plum Cultivars. Egypt. J. Hort.; Vol. 40, No.1, pp.121132

Nehra, D.S., S.K. Varam, J. Dayal and Kairon, M.S. 1987. Effect of ascorbic acid on fruiting and yield of cotton. Indian Journal of Plant Physiology, 30(4): 429-431

Özdemir, K.S. and Gökmen, V. 2017. Extending the shelf-life of pomegranate arils with chitosanascorbic acid coating. LWT-Food Science and Technology, 76, 172-180

P. Kendall and Sofos J. 2014. Drying fruits. Colorado State University, Extension Division.

[Online].1(1).pp.1.Available:

http://www.ext.colostate.edu/pubs/foo dnut/ 09309. Html

Paliyath, G. and J. Subramanian, Phospholipase D. 2008. Inhibition technology for enhancing shelf life and quality. In Paliyath, G., Murr, D.P., Handa, A.K and Lurie, S. (ed) Post-harvest Biology and Technology of Fruits, Vegetables, and Flowers, 1st ed. Pp 195- 239. Wiley-Blackwell, USA

Pesis, E., O. Dvir, O. Feygenberg, R.B. Arie, Lichter Ackerman, M. 1999. Production of acetaldehyde and ethanol during maturation and modified atmosphere storage of litchi fruit. Post-harvest Biology and Technology. 26,157-165
Ponting, J.D., R. Jackson and Watters, G. 1972. Refrigerated apple slice: preservative effects of ascorbic acid, calcium and sulfite. Journal of Food Science 37:434-436

Puthmee, T., P. Boonyaritthongchai and Kanlayanarat, S. 2009. Effect of ascorbic acid on shelf-life and quality of fresh cut 'Mahachanok' mango. In Southeast Asia Symposium on Quality and Safety of Fresh and FreshCut Produce 875 (pp. 223-226)

Rababah, T.M., K.I. Ereifej, Howard, L. 2005. Effect of ascorbic acid and dehydration on concentrations of total phenolics, antioxidant capacity, anthocyanins and color in fruits. $J$. Agric Food Chem. 1; 53(11): 44-47

Ragab, M.M. 2002. Effect of spraying urea ascorbic acid and NAA on fruiting of Washington Navel orange trees. M. Sc. Thesis. Fac. Agric. Minia. Univ. Egypt, pp:345-349

Rajput, R. P., H. J. Senjaliya, G. S Vala and Mangroliya, G. S. 2015. Effect of various plant growth regulators on yield and quality of guava (Psidium guajava L.) cv. LUCKNOW49. International Journal of Agricultural Sciences; 11(1), 179-182

Ramprasad, V., Reddy, Y. N. and Reddy, M. G. D. M. 2004. Studies on extension of shelf-life of grape through antioxidants and alternative inhibitors. Acta Hort. 662: 397-402

Santarre, C.R., J.N. Cash, and Vannorman, D.J. 1988. Ascorbic acid/citric acid combinations in the processing of frozen apple slices. Journal of Food Science, 53: 1713-1716

Sapers, G.M., K.B. Hicks, J.G. Philipps, L. Garzarella, D.L. Pondish, T.J. McCormick, S.M. Sondey, P.A. Scib, and El-Ataway, Y.S. 1989. Control of enzymatic browning in apple with ascorbic acid derivatives, polyphenol 
oxidase inhibitors and complexing agents. Journal of Food Science, 54: 997-1002

Siddiqui, S. and Gupta, O. P. 1989. Effect of pre-harvest spray of calcium on shelf life of ber (Ziziphus mauritiana Lamk.) fruits. Research and Development Reporter. 6:172-176

Siddiqui, S. and Gupta, O. P. 1995. "Effect of Post-Harvest Applications of Some Chemicals on Shelf Life of Ber (Zizyphus maurtiana Lamk) Fruits"; Haryana J. Hort. Sci., Vol. 24, No. 4, pp.19-23

Spanou, A. and Giannouli, P. 2013. Extend of Self-Life of Potato Round Slices with Edible Coating, Green Tea and Ascorbic Acid. World Academy of Science, Engineering and Technology, International Journal of Biological, Biomolecular, Agricultural, Food and Biotechnological Engineering, 7(7), 591-595

Sun, D., G. Liang, J. Xie, X. Lei and Mo, Y. 2010. Improved preserved effects of litchi by combining chitosan coating with ascorbic acid treatment during postharvest storage. African Journal Biotechnology, 9(22): 3272- 3279

Takeda. 2014. Vitamin C in food processing. Takeda Canada Vitamin and Food. Inc. Takeda U.S.A Inc. [Online].
1(1).pp.1.Available:

http://www.mratcliffe.com/images/vcb .pdf

Tomer, N.S. and Kumar, H. 1977. Effect of GA with ascorbic acid and sucrose on 'Perlette' grape. Indian Journal of Horticulture, 34(1): 30-33

Turmanidze, T., M. Jgenti, L. Gulua, and Shaiashvili, V. 2017. Effect of Ascorbic acid treatment on some quality parameters of frozen strawberry and raspberry fruits. Annals of Agrarian Science.; 15(3), 370-374

Wally, A.S., A. Nagwa, El-Megeed Abd and Fattma, Abou-Grah. 2012. Effect of gibberellic acid and two antioxidants on yield and fruit quality of "Canino" apricot trees. Minia International Conference for Agriculture and Irrigation in the Nile Basin Countries, 26 -29, El-Minia, Egypt

Wassel, A. M. 1984. White Banaty seedless grapes as influenced by gibberellic acid and ethephon. Bull. Fac. of Agric. Univ. Cairo .35(2), 1071-1082

Zhao, Z. H., M. J. Liu, P. Liu, X. Y. Liu, L. Dai, L. Yang, and Tian, S. L. 2009. Effects of citric acid treatments on post-harvest fruit quality of Zizyphus jujuba Mill. 'Linyilizao'. Acta Horticulturae, 840: 513-16

\section{How to cite this article:}

Jatinder Singh and Anis Mirza. 2018. Influence of Ascorbic Acid Application on Quality and Storage Life of Fruits. Int.J.Curr.Microbiol.App.Sci. 7(07): 4319-4328.

doi: https://doi.org/10.20546/ijcmas.2018.707.503 